\title{
Pandemic vaccination strategies and influenza severe outcomes during the influenza A(H1N1)pdm09 pandemic and the post-pandemic influenza season: the Nordic experience
}

J Gil Cuesta ${ }^{17}$, P Aavitsland ${ }^{2}$, H Englund ${ }^{3}$, Ó Gudlaugsson ${ }^{4}$, SH Hauge 5 , 0 Lyytikäinen ${ }^{6}$, G Sigmundsdóttir ${ }^{4}$, A Tegnell ${ }^{3}$, M Virtanen ${ }^{6}$, the Nordic influenza comparison group ${ }^{8}$, T Grove Krause ${ }^{1}$

1. Statens Serum Institut, Copenhagen, Denmark

2. Epidemi, Kristiansand, Norway

3. Public Health Agency Sweden, Stockholm, Sweden

4. Centre for Health Security and Communicable Disease Control, Reykjavik, Iceland

5. Norwegian Institute of Public Health, Oslo, Norway

6. National Institute for Health and Welfare, Helsinki, Finland

7. European Programme for Intervention Epidemiology Training (EPIET), European

8. Centre for Disease Prevention and Control (ECDC), Stockholm, Sweden.

9. The Nordic influenza comparison group members are listed at the end of the article

Correspondence: Julita Gil Cuesta (giljulita@gmail.com)

Gil Cuesta J, Aavitsland P, Englund H, Gudlaugsson Ó, Hauge SH, Lyytikäinen O, Sigmundsdóttir G, Tegnell A, Virtanen M, the Nordic influenza comparison group, Grove Krause T. Pandemic vaccination strategies and influenza severe outcomes during the influenza A(H1Ni)pdmog pandemic and the post-pandemic influenza season: the Nordic experience. Euro Surveill. 2016;21(16):pii=30208. DOI: http://dx.doi.org/10.2807/1560-7917.ES.2016.21.16.30208

During the 2009/10 influenza $A\left(\mathrm{H}_{1} \mathrm{~N}_{1}\right)$ pdmog pandemic, the five Nordic countries adopted different approaches to pandemic vaccination. We compared pandemic vaccination strategies and severe influenza outcomes, in seasons 2009/10 and 2010/11 in these countries with similar influenza surveillance systems. We calculated the cumulative pandemic vaccination coverage in 2009/10 and cumulative incidence rates of laboratory confirmed $\mathrm{A}\left(\mathrm{H}_{1} \mathrm{~N}_{1}\right)$ pdmog infections, intensive care unit (ICU) admissions and deaths in 2009/10 and $2010 / 11$. We estimated incidence risk ratios (IRR) in a Poisson regression model to compare those indicators between Denmark and the other countries. The vaccination coverage was lower in Denmark $(6.1 \%)$ compared with Finland (48.2\%), Iceland (44.1\%), Norway (41.3\%) and Sweden (60.0\%). In 2009/10 Denmark had a similar cumulative incidence of $A\left(\mathrm{H}_{1} \mathrm{~N}_{1}\right)$ pdmog ICU admissions and deaths compared with the other countries. In 2010/11 Denmark had a significantly higher cumulative incidence of $\mathrm{A}\left(\mathrm{H}_{1} \mathrm{~N}_{1}\right)$ pdmog ICU admissions (IRR: $2.4 ; 95 \%$ confidence interval (CI): 1.9-3.0) and deaths (IRR: 8.3; 95\% Cl: 5.1-13.5). Compared with Denmark, the other countries had higher pandemic vaccination coverage and experienced less $A\left(\mathrm{H}_{1} \mathrm{~N}_{1}\right)$ pdmog-related severe outcomes in 2010/11. Pandemic vaccination may have had an impact on severe influenza outcomes in the post-pandemic season. Surveillance of severe outcomes may be used to compare the impact of influenza between seasons and support different vaccination strategies.

\section{Background}

In 2009, the World Health Organization recommended adjuvanted vaccines in response to the $A\left(\mathrm{H}_{1} \mathrm{~N}_{1}\right)$ pdmog pandemic [1]. The five Nordic countries (Denmark, Finland, Iceland, Norway and Sweden) all used the monovalent ASo3-adjuvanted pandemic influenza vaccine Pandemrix [2].

Several studies have estimated the effectiveness of the pandemic vaccine in preventing $\mathrm{A}\left(\mathrm{H}_{1} \mathrm{~N}_{1}\right)$ pdmog during the pandemic [3-7]. In addition, others have shown an effect against influenza $A\left(\mathrm{H}_{1} \mathrm{~N}_{1}\right)$ pdmog in the postpandemic season as well as persistence of antibodies in children at sub-national or national level [8-10]. It is therefore possible that a high pandemic vaccination coverage in a population would affect the distribution of circulating influenza subtypes and disease severity for a longer period after a pandemic. We are not aware of any studies that assessed how different pandemic vaccination strategies may have affected the influenza type/subtype distribution and the epidemiology of severe influenza in the post-pandemic season.

The five Nordic countries are comparable with regards to demography [11], universal and equal access to the healthcare system [12], and healthcare practices [13]. They also had similar surveillance systems during the pandemic [14-18]. Furthermore, all Nordic countries established or strengthened their surveillance of severe influenza cases through reporting of influenza 


\section{FIGURE 1}

Cumulative pandemic vaccination coverage and laboratory-confirmed influenza $\mathrm{A}(\mathrm{H} 1 \mathrm{~N} 1) \mathrm{pdm} 09$, influenza B and A(H3N2) cases by week, influenza seasons 2009/10 and 2010/11, Denmark, Finland, Iceland, Norway and Sweden

A. Denmark

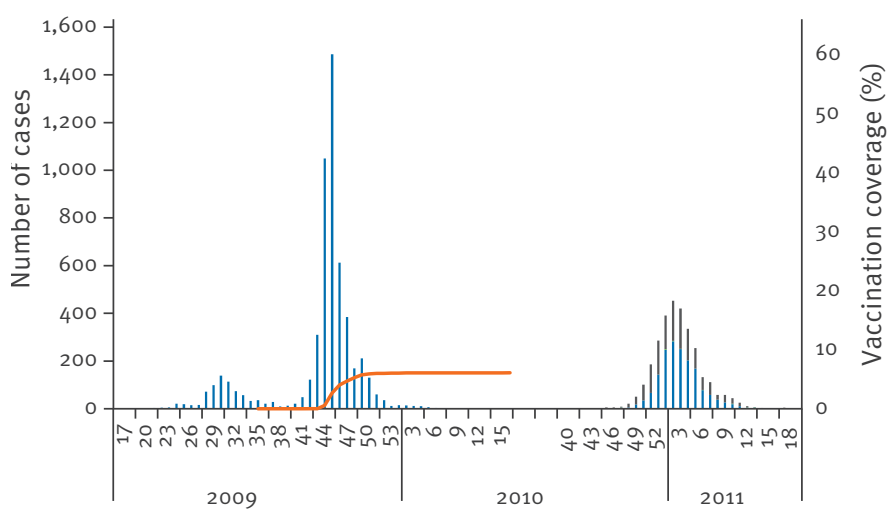

Week and season

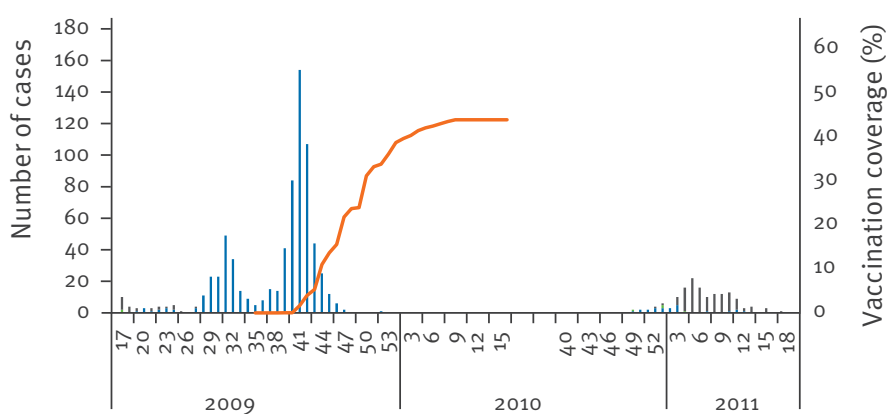

Week and season

\section{E. Sweden}

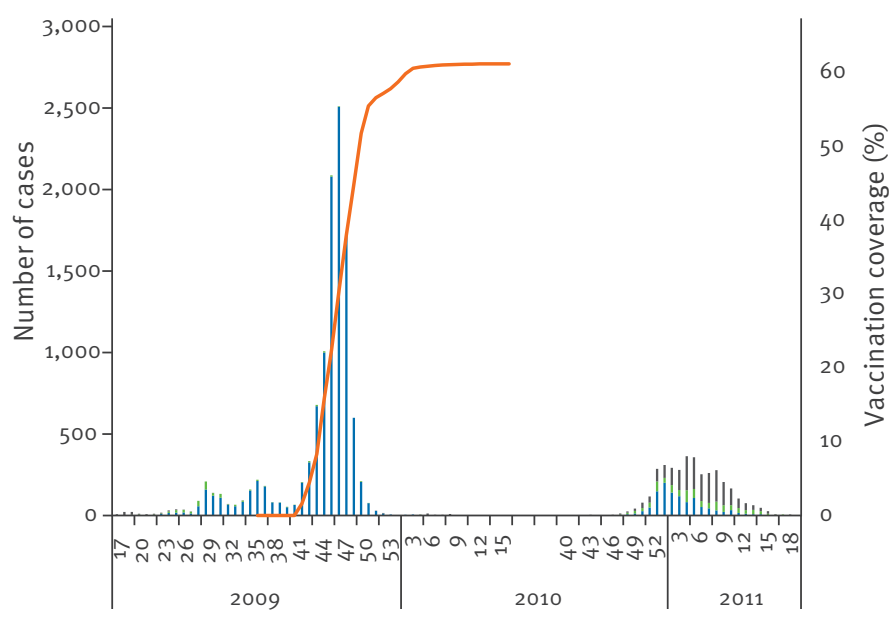

Week and season

B. Finland

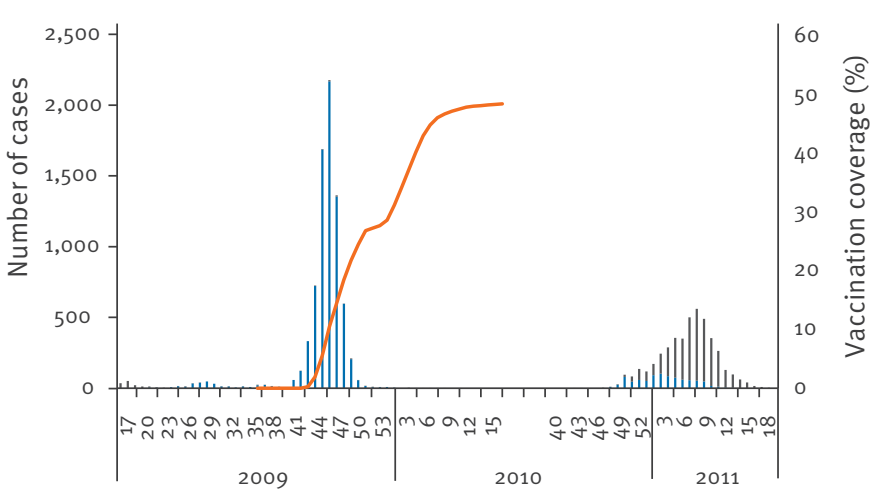

Week and season

\section{Norway}

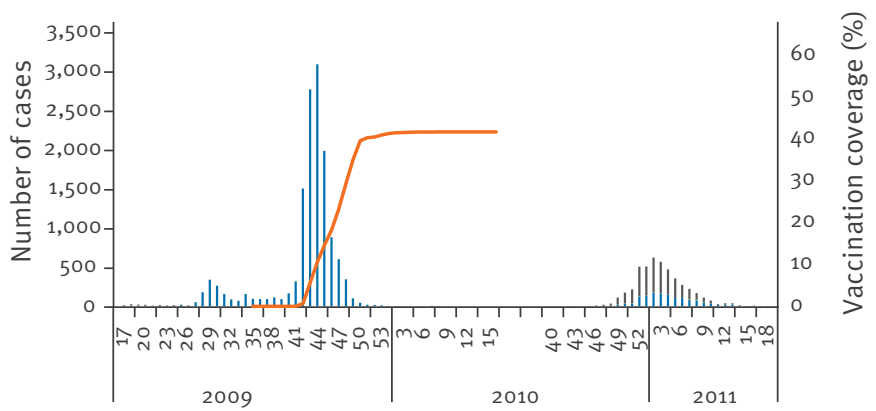

Week and season 


\section{FIGURE 2}

Influenza $\mathrm{A}(\mathrm{H} 1 \mathrm{~N} 1) \mathrm{pdm} 09$ and influenza $\mathrm{B}$ distribution by age group and country, Denmark, Finland, Iceland, Norway and Sweden, influenza seasons 2009/10 and $2010 / 11$

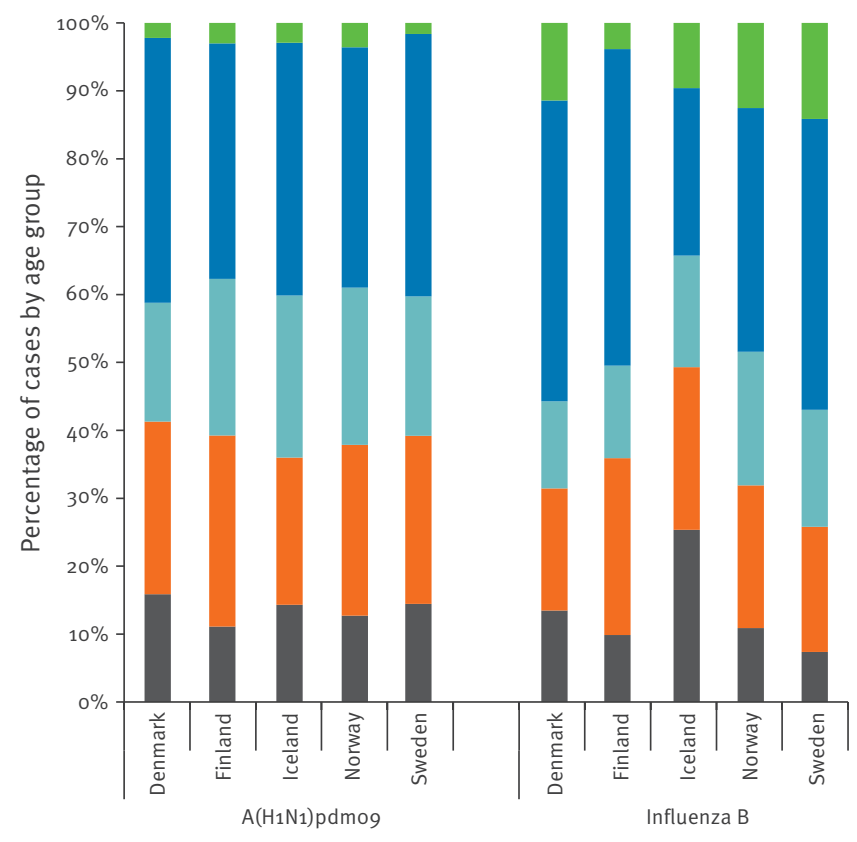

Influenza subtypes by countries

$$
\begin{array}{ll}
0-4 \text { years } & 15-24 \text { years } \quad 25-64 \text { years } \\
5-14 \text { years } & 25 \text { years }
\end{array}
$$

Distribution of influenza $\mathrm{A}\left(\mathrm{H}_{3} \mathrm{~N}_{2}\right)$ not shown due to small number of cases.

$\mathrm{A}\left(\mathrm{H}_{1} \mathrm{~N}_{1}\right)$ pdmo9-related intensive care unit (ICU) admissions and deaths in the 2009/10 and 2010/11 influenza seasons [14-19].

The objective of this study was to compare the five Nordic countries in terms of circulating influenza types/ subtypes and severe outcomes of influenza in the seasons $2009 / 10$ and $2010 / 11$ in relation to the pandemic vaccination coverage and the timing of vaccination.

\section{Methods}

\section{Study design and period}

We conducted an ecological study where we retrospectively compared aggregated data from two consecutive influenza seasons: the pandemic season 2009/10 (week 172009 - week 17 2010) and the post-pandemic season 2010/11 (week 402010 - week 20 2011) in the five Nordic countries.

\section{Data collection}

The national public health institutes of the five countries provided information about the recommendations for (i) pandemic vaccination such as target groups, beginning of vaccination campaigns and number of doses indicated, and (ii) virological sampling of patients with suspected influenza i.e. target groups and sampling protocols.

Each of the countries uses national unique personal identification numbers which enables the linkage of different national health registers but only aggregated data were provided for the current study. The public health institutes provided data on laboratoryconfirmed influenza cases by type/subtype, influenza $\mathrm{A}\left(\mathrm{H}_{1} \mathrm{~N}_{1}\right)$ pdmo9-related ICU admissions, influenzarelated deaths, and the percentage of samples that tested positive for influenza from laboratories as well as the number of persons vaccinated. These numerator data were stratified by week of the influenza season. We obtained population denominators from Eurostat [11].

\section{Definitions}

The weekly and cumulative pandemic vaccination coverages were calculated based on the individual registration of vaccinated individuals from each country by dividing the number of vaccinated individuals by the country population.

Notification of confirmed influenza $A\left(\mathrm{H}_{1} \mathrm{~N}_{1}\right)$ pdmog cases was mandatory in Finland, Iceland, Norway and Sweden $[15,16,20]$. In Denmark, notification was only mandatory in the $2009 / 10$ season [17]. In season $2010 / 11$, information on laboratory-confirmed cases was obtained from a newly established national database comprising all influenza test results [21]. Therefore, all laboratories in each of the Nordic countries were included in the reporting. The weekly and cumulative incidences of laboratory-confirmed influenza $A\left(\mathrm{H}_{1} \mathrm{~N}_{1}\right)$ pdmo9, $A\left(\mathrm{H}_{3} \mathrm{~N}_{2}\right)$ and influenza $B$ cases were calculated by dividing the number of cases by 100,000 country population for each season.

We defined severe outcomes of influenza $A\left(\mathrm{H}_{1} \mathrm{~N}_{1}\right)$ pdmog as influenza-related ICU admissions and deaths. During the pandemic, the surveillance of the $A\left(\mathrm{H}_{1} \mathrm{~N}_{1}\right)$ pdmog cases included all ICUs in each of the five Nordic countries. The testing recommendations at hospital level were to swab all patients hospitalised with influenza-like illness symptoms or lower airway infections during the pandemic [22-24]. The $A\left(\mathrm{H}_{1} \mathrm{~N}_{1}\right)$ pdmog testing recommendations did not change during the $2010 / 11$ season $[25,26]$. The cumulative incidences of influenza-related ICU admissions were calculated by dividing the number of patients admitted to the ICUs and diagnosed with influenza $A\left(\mathrm{H}_{1} \mathrm{~N}_{1}\right)$ pdmog by 100,000 country population for each season.

The number of influenza-related deaths was identified by obtaining information from the civil registry on date of death among the $\mathrm{A}\left(\mathrm{H}_{1} \mathrm{~N}_{1}\right)$ pdmog confirmed cases in Denmark, Finland and Sweden. Deaths that occurred within 30 days after the last influenza positive sample were considered. Each case was then reviewed and validated by national medical officers. In Iceland and 
Timing of recommendations of pandemic vaccination to target groups in Denmark, Finland, Iceland, Norway and Sweden, during the 2009/10 influenza A(H1N1)pdm09 pandemic

\begin{tabular}{|c|c|c|c|c|}
\hline \multirow[b]{2}{*}{ Country } & \multicolumn{4}{|c|}{ Target groups recommended by week } \\
\hline & Underlying conditions ${ }^{a}$ & $\begin{array}{l}\text { Healthcare workers and key } \\
\text { community professions }^{b}\end{array}$ & Pregnant women & $\begin{array}{c}\text { Healthy population } \geq 6 \\
\text { months of age }\end{array}$ \\
\hline Denmark & $\begin{array}{l}\text { Week 43: }<65 \text { years of age } \\
\text { Week 49: } \geq 65 \text { years of age }\end{array}$ & Week 43 & $\begin{array}{l}\text { Week } 45: 2^{\text {nd }} \text { and } 3^{\text {rd }} \\
\text { trimester }\end{array}$ & Not recommended \\
\hline Finland & Week 45 & Week 43 & Week 44 & $\begin{array}{c}\text { Week 46: 6-35 months } \\
\text { Week 47: 3-24 years }\end{array}$ \\
\hline Iceland & Week 45 & Week 42-43 & Week 45 & Week 48 \\
\hline Norway & Week 38 & Week 38 & Week 38 & Week 43 \\
\hline Sweden & Week 42 & Week 42 & Week 42 & Week $44-46^{c}$ \\
\hline
\end{tabular}

a The countries included one or more of the following: pulmonary diseases, cardiovascular diseases, haemoglobinopathies, diabetes type 1 or 2, congenital or acquired immune deficiencies, neuromuscular conditions, chronic liver or renal failure, other diagnoses which pose a serious health risk in conjunction with influenza.

${ }^{\mathrm{b}}$ The countries included one or more of the following: police, firemen, firefighters, etc.

${ }^{\mathrm{c}}$ According to regional planning.

Norway, a case-based reporting of all deaths associated with $\mathrm{A}\left(\mathrm{H}_{1} \mathrm{~N}_{1}\right)$ pdmog was in place from hospitals and healthcare facilities. The influenza-related mortality was calculated by dividing the number of influenza confirmed deaths by 100,000 country population for each season.

\section{Data analysis}

The pandemic vaccination coverage during the pandemic season was compared between the five countries.

In each influenza season, we compared the country incidence of laboratory-confirmed influenza by type/ subtype, $\mathrm{A}\left(\mathrm{H}_{1} \mathrm{~N}_{1}\right)$ pdmog-related ICU-admissions and the $A\left(\mathrm{H}_{1} \mathrm{~N}_{1}\right)$ pdmog-related mortality. These indicators were also compared by age groups.

A Poisson regression model was used to compare the indicators between the Nordic countries for each influenza season. We estimated the incidence risk ratio (IRR) and corresponding 95\% confidence intervals (CI) for Denmark vs the other four countries, using the other countries as a reference. The statistical analysis was carried out using Stata 12 software.

\section{Ethical considerations}

The study only included aggregated surveillance data without personal identifiers. Therefore, no ethical approval was needed according to each country's national regulations.

\section{Results}

\section{Vaccination recommendations and coverage} during the pandemic

In 2009, all countries recommended pandemic vaccination for healthcare workers, pregnant women and individuals aged six months or more with one or more chronic medical condition which increased the risk for influenza-related complications, from week 38 to 45 (Table 1). In addition, Finland, Iceland, Norway and Sweden but not Denmark, recommended vaccination to the whole population aged six months of age or more from week 43 to 48 .

Finland, Iceland and Norway recommended one vaccine dose for individuals aged 10 years or more. Sweden and Denmark started by recommending two doses and changed to one dose in week 46 and 49 of 2009 , respectively, for individuals aged above 10 years old with a functioning immune system. Denmark, Iceland, Norway and Sweden recommended two doses for children below 10 years of age, while Finland recommended only one dose in this age group. Norway changed the recommendation to one dose in the same age group in week 51 .

The Nordic countries started to administer the vaccine in September in Finland and in October 2009 in Denmark, Iceland, Norway and Sweden. The cumulative coverage of administered vaccines by the end of the pandemic was significantly lower in Denmark, 6.1\%, compared with Finland, 48.2\%, Iceland 44.1\%, Norway $41.3 \%$ and Sweden $60.0 \%$. The percentage of vaccinated children below five years of age in Denmark was $0.3 \%$, in Finland $73 \%$, in Iceland $43 \%$ and in Norway $47 \%$; data for Sweden was not available. The percentage of vaccinated population above 65 years of age in Denmark was $18 \%$, compared with $49 \%$ in Finland, $59 \%$ in Iceland and 53\% in Norway. In the 2010/11 season, the trivalent seasonal influenza vaccine (TIV) included $A\left(\mathrm{H}_{1} \mathrm{~N}_{1}\right) p d m o 9$ as one of the three viruses, and this vaccine type was used in all five countries; Pandemrix was not in use during this season. 
Rates of laboratory-confirmed influenza A(H1N1)pdm09 and ICU admissions and deaths related to influenza A(H1N1) pdm09, influenza seasons 2009/10 and 2010/11, Denmark, Finland, Iceland, Norway and Sweden

\begin{tabular}{|c|c|c|c|c|c|c|c|c|c|c|c|c|}
\hline \multirow[b]{3}{*}{ Country } & \multicolumn{4}{|c|}{ Laboratory-confirmed $\mathrm{A}\left(\mathrm{H}_{1} \mathrm{~N}_{1}\right) \mathrm{pdmog}$} & \multicolumn{4}{|c|}{$\mathrm{A}\left(\mathrm{H}_{1} \mathrm{~N}_{1}\right)$ pdmo9-related ICU admissions } & \multicolumn{4}{|c|}{$\mathrm{A}\left(\mathrm{H}_{1} \mathrm{~N}_{1}\right) \mathrm{pdmog}$-related deaths } \\
\hline & \multicolumn{2}{|c|}{ Season $2009 / 10$} & \multicolumn{2}{|c|}{ Season $2010 / 11$} & \multicolumn{2}{|c|}{ Season $2009 / 10$} & \multicolumn{2}{|c|}{ Season $2010 / 11$} & \multicolumn{2}{|c|}{ Season $2009 / 10$} & \multicolumn{2}{|c|}{ Season $2010 / 11$} \\
\hline & $\mathrm{n}$ & $\begin{array}{c}\text { Incidence } \\
\mathrm{n} / 100,000 \\
(95 \% \mathrm{Cl})\end{array}$ & $\mathrm{n}$ & $\begin{array}{c}\text { Incidence } \\
\mathrm{n} / 100,000 \\
(95 \% \mathrm{Cl})\end{array}$ & $\mathrm{n}$ & $\begin{array}{c}\text { Incidence } \\
\mathrm{n} / 100,000 \\
(95 \% \mathrm{Cl})\end{array}$ & $\mathrm{n}$ & $\begin{array}{c}\text { Incidence } \\
\mathrm{n} / 100,000 \\
(95 \% \mathrm{Cl})\end{array}$ & $\mathrm{n}$ & $\begin{array}{c}\text { Incidence } \\
\text { n/100,000 } \\
(95 \% \mathrm{Cl})\end{array}$ & $\mathrm{n}$ & $\begin{array}{l}\text { Incidence } \\
\mathrm{n} / 100,000 \\
(95 \% \mathrm{Cl})\end{array}$ \\
\hline Denmark & 5,497 & $\begin{array}{c}99.3 \\
(96.7- \\
101.9)\end{array}$ & 1,671 & $\begin{array}{c}30.2 \\
(28.7- \\
31.6)\end{array}$ & 93 & $\begin{array}{c}1.6 \\
(1.3-2.0)\end{array}$ & 106 & $1.9(1.5-2.3)$ & 30 & $0.5(0.3-0.7)$ & 53 & $\begin{array}{c}0.9 \\
(0.7-1.2)\end{array}$ \\
\hline Finland & 7,666 & $\begin{array}{c}143.2 \\
(140.0- \\
146.4)\end{array}$ & 877 & $\begin{array}{c}16.3 \\
(15 \cdot 3-17 \cdot 5)\end{array}$ & 133 & $\begin{array}{c}2.4 \\
(2.0-2.9)\end{array}$ & 52 & $0.9(0.7-1.2)$ & 44 & $0.8(0.6-0.1)$ & 13 & $\begin{array}{c}0.2 \\
(0.1-0.4)\end{array}$ \\
\hline Iceland & 696 & $\begin{array}{c}219.1 \\
\left(203.4^{-}\right. \\
236.0)\end{array}$ & 24 & $\begin{array}{c}7.5 \\
(5.0-11.3)\end{array}$ & 17 & $\begin{array}{c}5 \cdot 3 \\
(3 \cdot 3-8.6)\end{array}$ & 1 & $0.3(0.04-2.2)$ & 2 & $0.6(0.1-2.5)$ & 0 & 0 \\
\hline Norway & 13,707 & $\begin{array}{c}282.1 \\
(277.4- \\
286.9)\end{array}$ & 1,365 & $\begin{array}{c}28.0 \\
(26.6- \\
29.6)\end{array}$ & 147 & $\begin{array}{c}3.0 \\
(2.5-3.5)\end{array}$ & 43 & $0.8(0.6-1.1)$ & 32 & $0.6(0.4-0.9)$ & 1 & $\begin{array}{c}0.02 \\
(0.00-0.1)\end{array}$ \\
\hline Sweden & 11,002 & $\begin{array}{c}117.7 \\
(115.6- \\
120.0)\end{array}$ & 1,125 & $\begin{array}{c}12.0 \\
(11.3-12.7)\end{array}$ & 116 & $\begin{array}{c}1.2 \\
(1.0-1.4)\end{array}$ & 64 & $0.6(0.5-0.8)$ & 36 & $0.3(0.2-0.5)$ & 9 & $\begin{array}{c}0.09 \\
(0.05-0.2)\end{array}$ \\
\hline & \multicolumn{2}{|c|}{$p$ value $<0.001$} & \multicolumn{2}{|c|}{$\mathrm{p}$ value $<0.001$} & \multicolumn{2}{|c|}{$\mathrm{p}$ value $<0.001$} & \multicolumn{2}{|c|}{$p$ value $<0.001$} & \multicolumn{2}{|c|}{$p$ value $<0.05$} & \multicolumn{2}{|c|}{$p$ value $<0.001$} \\
\hline
\end{tabular}

n: number; $\mathrm{Cl}$ : confidence interval; ICU: intensive care unit.

$\mathrm{p}$ values were calculated through Poisson regression.

Incidence of laboratory-confirmed influenza and recommendations for testing

The weekly incidence of reported laboratory confirmed $\mathrm{A}\left(\mathrm{H}_{1} \mathrm{~N}_{1}\right)$ pdmog cases peaked in week 42 of 2009 in Iceland, week 45 in Norway, week 46 in Denmark and Finland and week 47 in Sweden. At the peak in each country, the cumulative pandemic vaccine coverage was below $10 \%$ for all countries except Sweden, where it was 30\% (Figure 1).

During the pandemic, the influenza $A\left(\mathrm{H}_{1} \mathrm{~N}_{1}\right)$ pdmog virus was predominant among laboratory-confirmed influenza cases compared with influenza $B$ and $A\left(\mathrm{H}_{3} \mathrm{~N}_{2}\right)$ viruses in the five Nordic countries. In Finland there was only information on $\mathrm{A}\left(\mathrm{H}_{1} \mathrm{~N}_{1}\right)$ pdmog, but not on other subtypes of influenza A (Figure 1). In the 2010/11 season, influenza B was predominant in Finland, Iceland, Norway and Sweden, contrary to Denmark where $\mathrm{A}\left(\mathrm{H}_{1} \mathrm{~N}_{1}\right)$ pdmog was predominant (Figure 1).

In 2009/10, the incidence of laboratory-confirmed $A\left(\mathrm{H}_{1} \mathrm{~N}_{1}\right)$ pdmog influenza was significantly lower in Denmark compared with the other four Nordic countries (IRR: 0.6; 95\% Cl: 0.6-0.6; p value <0.001) (Table 2 , 3). In 2010/11, the cumulative incidence of $A\left(\mathrm{H}_{1} \mathrm{~N}_{1}\right)$ pdmog influenza was lower in all countries compared with 2009/10 (Table 2). In contrast to the previous season, it was significantly higher in Denmark than in the other four Nordic countries (IRR: 1.8; 95\% Cl: 1.7-1.9; $\mathrm{p}$ value $<0.001$ ) (Table 2,3 .

Recommended target groups for testing were similar in the five countries. The swabbing of cases and their contacts started in week 17 in Sweden, week 18 in Denmark, Finland and Norway and week 21 in Iceland. The swabbing recommendations changed to only risk group patients or close contacts of confirmed cases in all countries from week 29 in Denmark and Sweden, week 30 in Norway, week 31 in Finland and week 33 in Iceland (Table 4).

The number of positive $\mathrm{A}\left(\mathrm{H}_{1} \mathrm{~N}_{1}\right)$ pdmog cases among the total tested was available in Iceland (19.6\%), Norway $(21.4 \%)$ and Sweden (23.6\%) in the $2009 / 10$ season. In season 2010/11, the percentage of positives decreased in the three countries and was 3.5\% in Iceland, $6.4 \%$ in Norway and $6.2 \%$ in Sweden.

\section{Influenza A(H1N1)pdm09-related ICU admissions and mortality}

During the pandemic season, the incidence of $A\left(\mathrm{H}_{1} \mathrm{~N}_{1}\right)$ pdmog-related ICU admissions was statistically significantly lower in Denmark and Sweden than in Finland, Iceland and Norway (Table 2). In the 2010/11 season, the incidence was lower than during the pandemic in all countries except for Denmark. In 2010/11, Denmark had a higher incidence of $A\left(\mathrm{H}_{1} \mathrm{~N}_{1}\right)$ pdmog-related ICU admissions (IRR: $2.4 ; 95 \% \mathrm{Cl}: 1.9-3.0 ; \mathrm{p}$ value $<0.001$ ) compared with the other Nordic countries (Table 2,3).

In the 2009/10 season, there were no statistically significant differences between the influenza $A\left(\mathrm{H}_{1} \mathrm{~N}_{1}\right)$ pdmog-related mortality in the five countries (Table $2,3)$. In 2010/11, the influenza $A\left(\mathrm{H}_{1} \mathrm{~N}_{1}\right)$ pdmog-related mortality was significantly higher in Denmark compared 
Rates of laboratory-confirmed influenza A(H1N1)pdm09 and influenza B cases, ICU admissions and mortality due to influenza $\mathrm{A}(\mathrm{H} 1 \mathrm{N1})$ pdm09 in Denmark compared with the other countries (Finland, Iceland, Norway and Sweden), influenza seasons 2009/10 and 2010/11

\begin{tabular}{|c|c|c|c|c|c|c|c|c|c|c|c|c|}
\hline \multirow{3}{*}{$\begin{array}{l}\text { Rates of laboratory- } \\
\text { confirmed influenza } \\
\mathrm{A}\left(\mathrm{H}_{1} \mathrm{~N}_{1}\right) \text { pdmog and } \\
\text { influenza B cases, } \\
\mathrm{A}\left(\mathrm{H}_{1} \mathrm{~N}_{1}\right) \text { pdmog ICU } \\
\text { admissions and } \\
\text { mortality }\end{array}$} & \multicolumn{6}{|c|}{ Season $2009 / 10$} & \multicolumn{6}{|c|}{ Season $2010 / 11$} \\
\hline & \multicolumn{4}{|c|}{ Denmark } & \multicolumn{2}{|c|}{ Other countries ${ }^{a}$} & \multicolumn{4}{|c|}{ Denmark } & \multicolumn{2}{|c|}{ Other countries ${ }^{\mathrm{a}}$} \\
\hline & $\begin{array}{l}\text { Incidence } \\
\mathrm{n} / 100,000\end{array}$ & $\begin{array}{c}95 \% \\
\mathrm{Cl}\end{array}$ & $\begin{array}{c}I^{\prime R R^{b}} \\
(95 \% \\
C l)\end{array}$ & $p$ value & $\begin{array}{l}\text { Incidence } \\
\mathrm{n} / 100,000\end{array}$ & $95 \% \mathrm{Cl}$ & $\begin{array}{l}\text { Incidence } \\
/ 100,000\end{array}$ & $\begin{array}{c}95 \% \\
\mathrm{Cl}\end{array}$ & IRR $^{b}$ & $\mathrm{p}$ value & $\begin{array}{l}\text { Incidence } \\
/ 100,000\end{array}$ & $\begin{array}{c}95 \% \\
\mathrm{Cl}\end{array}$ \\
\hline $\mathrm{A}\left(\mathrm{H}_{1} \mathrm{~N}_{1}\right) \mathrm{pdmog}$ & $99 \cdot 3$ & $\begin{array}{l}96.7^{-} \\
102.0\end{array}$ & $\begin{array}{c}0.6 \\
(0.6- \\
0.6)\end{array}$ & $p<0.001$ & 166.4 & $\begin{array}{c}164 \cdot 7^{-} \\
168.2\end{array}$ & 30.2 & $\begin{array}{c}28.8- \\
31.7\end{array}$ & $\begin{array}{c}1.8 \\
(1.7- \\
1.9)\end{array}$ & $p<0.001$ & 16.9 & $\begin{array}{c}16.4^{-} \\
17 \cdot 5\end{array}$ \\
\hline Influenza B & NA & NA & NA & NA & NA & NA & 23.4 & $\begin{array}{c}22.1- \\
24 \cdot 7\end{array}$ & $\begin{array}{c}0.5 \\
\left(0.5^{-}\right. \\
0.5)\end{array}$ & NA & $43 \cdot 7$ & $\begin{array}{l}42.8- \\
44.6\end{array}$ \\
\hline $\begin{array}{l}\mathrm{A}\left(\mathrm{H}_{1} \mathrm{~N}_{1}\right) \text { pdmog-related } \\
\text { ICU admissions }\end{array}$ & 1.7 & $\begin{array}{c}1.4^{-} \\
2.0\end{array}$ & \begin{tabular}{|c|}
0.8 \\
$(0.6-$ \\
$1.0)$ \\
\end{tabular} & $p=0.064$ & 2.1 & $1.9-2.3$ & 1.9 & $\begin{array}{c}1.6- \\
2.3\end{array}$ & $\begin{array}{c}2.4 \\
(1.9- \\
3.0) \\
\end{array}$ & $p<0.001$ & 0.8 & $\begin{array}{l}0.7- \\
0.9\end{array}$ \\
\hline $\begin{array}{l}\mathrm{A}\left(\mathrm{H}_{1} \mathrm{~N}_{1}\right) \text { pdmo9-related } \\
\text { mortality }\end{array}$ & 0.5 & $\begin{array}{c}0.4^{-} \\
0.8\end{array}$ & $\begin{array}{c}0.9 \\
(0.6- \\
1.4)\end{array}$ & $p=0.781$ & 0.6 & $0.5-0.7$ & 0.9 & $\begin{array}{c}0.7- \\
1.2\end{array}$ & $\begin{array}{c}8.3 \\
(5.1- \\
13.5)\end{array}$ & $p<0.001$ & 0.1 & $\begin{array}{c}0.1- \\
0.2\end{array}$ \\
\hline
\end{tabular}

$\mathrm{Cl}$ : confidence interval; ICU: intensive care unit; IRR: incidence risk ratio; NA: not available.

a Other countries: Finland, Iceland, Norway and Sweden.

${ }^{b}$ Reference group: Other countries.

with the other countries (IRR: $8.3 ; 95 \% \mathrm{Cl}: 5.1-13.5 ; \mathrm{p}$ value<0.001).

\section{Discussion}

There was a wide variation in pandemic vaccination strategies during the pandemic in Europe, and the influenza $A\left(\mathrm{H}_{1} \mathrm{~N}_{1}\right)$ pdmog pandemic vaccination coverage previously reported for the entire population ranged from $0.5 \%$ to $59 \%$ across European countries [27]. We evaluated how the pandemic and the post-pandemic influenza seasons progressed in the Nordic countries and present the results in light of the different vaccination strategies used. A similar approach would have been difficult at the European level due to the heterogeneous populations, different healthcare and different influenza surveillance systems. The Nordic countries are comparable regarding these factors which gave us a unique opportunity to study differences in severe outcomes of influenza $A\left(\mathrm{H}_{1} \mathrm{~N}_{1}\right)$ pdmog in the pandemic and post-pandemic seasons in relation to the vaccination coverage during the pandemic.

The pandemic vaccination coverage was 6\% in Denmark where vaccination was only recommended for at-risk groups, compared with 41 to $60 \%$ in the other four Nordic countries where vaccination was recommended for the whole population. The timeliness of vaccination varied by a few weeks with Sweden having the highest proportion of the population vaccinated before the epidemic peak.

All Nordic countries reported that the most frequent influenza type during the pandemic was $A\left(\mathrm{H}_{1} \mathrm{~N}_{1}\right)$ pdmo9, with Denmark and Sweden having the lowest rates of laboratory-confirmed $\mathrm{A}\left(\mathrm{H}_{1} \mathrm{~N}_{1}\right)$ pdmog cases overall and cases admitted to ICU. However, in the following influenza season, 2010/11, $\mathrm{A}\left(\mathrm{H}_{1} \mathrm{~N}_{1}\right)$ pdmog dominated in Denmark, whereas influenza type $B$ was the predominant virus in the other four Nordic countries. Furthermore, in the 2010/11 season, Denmark experienced a higher incidence of $\mathrm{A}\left(\mathrm{H}_{1} \mathrm{~N}_{1}\right)$ pdmog-related ICU admissions and deaths than the other Nordic countries.

The higher incidence of laboratory-confirmed influenza $A\left(\mathrm{H}_{1} \mathrm{~N}_{1}\right)$ pdmog cases and related ICU admissions and deaths in Denmark in the 2010/11 season could be due to less natural or vaccine-induced immunity in the population in the post-pandemic season compared with the other countries. Studies on the burden of the pandemic influenza in Denmark have estimated a clinical attack rate of $5 \%$ [28] which is indeed lower than the clinical attack rate of $30 \%$ estimated in Norway [29]. However, the latter number was obtained by using a different method [29]. Clinical attack rates were not available for the other Nordic countries.

Other European countries have reported findings similar to those observed in Denmark. In 2010/11, the United Kingdom (UK) reported a higher level of daily number of confirmed and suspected influenza cases in critical care and a higher number of deaths compared with the 2009/10 pandemic season [30,31]. Pandemic vaccination coverage was estimated to be $15 \%$ for the general population in Scotland [32]. The coverage was 35\% for the risk groups in the UK where it provided some protection against laboratory-confirmed influenza $A\left(\mathrm{H}_{1} \mathrm{~N}_{1}\right)$ 
TABLE 4

Timing of recommendations of influenza testing, Denmark, Finland, Iceland, Norway and Sweden, 2009/10 influenza $\mathrm{A}(\mathrm{H} 1 \mathrm{~N} 1)$ pdm09 pandemic

\begin{tabular}{|l|c|c|}
\hline \multirow{2}{*}{ Country } & \multicolumn{2}{|c|}{ Groups recommended for testing and week } \\
\cline { 2 - 3 } & $\begin{array}{c}\text { Cases }{ }^{\text {a }} \text { and their } \\
\text { contacts }\end{array}$ & $\begin{array}{c}\text { Cases at risk of severe disease } \\
\text { and their contacts }\end{array}$ \\
\hline Denmark & Week 18 & Week 29 \\
\hline Finland & Week 18 & Week 31 \\
\hline Iceland & Week 21 & Week 33 \\
\hline Norway & Week 18 & Week 30 \\
\hline Sweden & Week 17 & Week 29 \\
\hline
\end{tabular}

a Individuals fulfilling the national case definition for suspected case of influenza $\mathrm{A}\left(\mathrm{H}_{1} \mathrm{~N}_{1}\right)$ pdmog.

pdmog in the 2010/11 season according to a vaccine effectiveness study [10]. In Greece, where a 3\% population pandemic vaccination coverage was reported, higher ICU admission rates and higher overall population mortality due to influenza $A\left(\mathrm{H}_{1} \mathrm{~N}_{1}\right)$ pdmog was also reported in 2010/11 compared with the previous season [33]. In Ireland, $23 \%$ of the population eligible for vaccination was vaccinated during the pandemic and the number of influenza $\mathrm{A}\left(\mathrm{H}_{1} \mathrm{~N}_{1}\right)$ pdmog-related ICU admissions and deaths increased from the 2009/10 to the 2010/11 influenza season [34].

Adjuvanted vaccines have shown to provide longer lasting immunity in children, adults and populations with chronic conditions compared with non-adjuvanted vaccines $[8,9,35]$. They induce antibodies that show higher levels of haemagglutination inhibition and influenza-neutralising activity than non-adjuvanted vaccines [36-38]. In addition, the 2009 pandemic vaccine strain closely matched the influenza $A\left(\mathrm{H}_{1} \mathrm{~N}_{1}\right)$ pdmog virus strain that circulated during the season 2010/11. Thus, in 2010/11 the population of the Nordic countries could have been protected to some extent by the pandemic vaccine administered more than one year earlier.

Several national and sub-national studies have reported the prevailing effectiveness of the pandemic vaccine in $2009 / 10$ in preventing influenza $A\left(\mathrm{H}_{1} \mathrm{~N}_{1}\right)$ pdmog during season 2010/11. In Sweden, the pandemic vaccine effectiveness (VE) was $72 \%$ against hospitalisation in 2010/11 [8]. In Finland, the VE against $A\left(\mathrm{H}_{1} \mathrm{~N}_{1}\right)$ pdmo9 influenza was $81 \%$ if vaccinated with pandemic vaccine and $88 \%$ if vaccinated with either pandemic vaccine or TIV in 2010/11 [39]. In UK, the VE against $A\left(\mathrm{H}_{1} \mathrm{~N}_{1}\right)$ pdmog in $2010 / 11$ was $34 \%$ if vaccinated with pandemic vaccine; $46 \%$ if vaccinated with TIV in 2010/11 and $63 \%$ if vaccinated with both [10]. These results are in line with our findings of a lower incidence of severe influenza outcomes in 2010/11 in the four countries with higher pandemic vaccination coverage compared with Denmark.

\section{Limitations}

Although the five Nordic countries have similar healthcare systems, they may have had different testing practices for influenza confirmation and subtyping, and thus ascertainment of the diagnosis. This would have affected the comparability of the data between countries and between the two seasons. This limitation is however minimised due to three facts. Firstly, testing recommendations were similar in the five countries from the beginning of the pandemic and changed to only risk group patients or close contacts of laboratoryconfirmed cases in all countries from week 29 to 32 . Furthermore, testing bias probably did not affect the ICU admission rates, as the testing recommendations at hospital level (including ICU units) in all countries were to swab all patients hospitalised with influenza symptoms or lower airway infection [22-26]. Secondly, the proportion of specimens positive for influenza was similar among the three countries with available information which may additionally indicate that the case ascertainment was comparable throughout this period. The percentage of positive samples reflects the influenza transmission if systematically sampled e.g. in sentinel systems. But different criteria for diagnostic swabbing of symptomatic patients (e.g. more severely ill patients with higher likelihood of being influenza positive) could also have accounted for differences in the percentage between countries. Thirdly, the age distribution of laboratory-confirmed influenza $A\left(\mathrm{H}_{1} \mathrm{~N}_{1}\right)$ pdmog and influenza B was similar (Figure 2) between the countries in the two seasons which also points towards a comparable case ascertainment. In addition, the testing practices may have changed due to different disease awareness during the pandemic and the following year. However, there is no evidence that changes in disease awareness between the two seasons would have differed markedly between the countries concerned.

Data on the TIV coverage in the five countries in $2009 / 10$ and 2010/11 seasons was not included in the analysis, as it was not available for all countries. This could have influenced the morbidity and mortality due to influenza in both seasons, as in Canada, where studies have shown an increased risk of influenza $A\left(\mathrm{H}_{1} \mathrm{~N}_{1}\right)$ pdmog in 2009/10 among TIV recipients in 2008/09 [40]. Therefore, the TIV in 2009/10 and 2010/11 could have influenced the morbidity and mortality due to influenza in both seasons. However, in the Nordic countries the TIV was only offered to the risk groups and not to the general population, and it is therefore likely to have had a minor impact on the overall incidence of disease. In addition, the coverage in 2010/11 would only have had an impact on the results if there were differences in the risk groups or coverages in the other Nordic countries compared with Denmark. This is not the case since the seasonal vaccination recommendations were similar in the Nordic countries and included the same risk groups, except for the recommendation of vaccinating healthy children in Finland [41]. Moreover, vaccination coverages in the season 
2010/11 were similar in three of the Nordic countries in the elderly population: $50 \%$ in Denmark, $47 \%$ in Norway among elderly and risk groups, and $54 \%$ in Sweden [42].

The optimal design to address a prolonged effect of the pandemic vaccine would have been a multi-country register-based study with individual level information on pandemic and seasonal vaccinations and influenza $\mathrm{A}\left(\mathrm{H}_{1} \mathrm{~N}_{1}\right)$ pdmog outcomes. If this data had been available it would have been possible to conduct pandemic VE analysis with stratification on previous TIV vaccination in the two seasons.

Finally, it is a limitation that we only included information on vaccination coverage as a predictor of severe outcomes of influenza, when influenza transmission is known to be influenced by a range of factors other than vaccination such as population density, social factors, weather conditions and latitude which were not taken into account in this study.

\section{Conclusions and recommendations}

Our observational study allowed a comprehensive description of timing and coverage of the pandemic vaccinations and severe outcomes of influenza $A\left(\mathrm{H}_{1} \mathrm{~N}_{1}\right)$ pdmog during the pandemic and following season in the five Nordic countries.

In response to the $\mathrm{A}\left(\mathrm{H}_{1} \mathrm{~N}_{1}\right)$ pdmog pandemic, Finland, Iceland, Norway and Sweden recommended vaccination to the whole population at a certain time of the pandemic and reached coverages of 41 to $60 \%$, whereas Denmark throughout the pandemic only recommended to vaccinate risk groups, leading to a coverage of $6 \%$ of the population. This difference does not seem to have influenced the timing of the epidemic nor the disease burden in the 2009/10 pandemic season, probably because the vaccines were distributed too late relative to the epidemic peak. However, in the following influenza season 2010/11, the four countries with higher pandemic vaccination coverage experienced a season dominated by influenza $B$ and had less influenza $A\left(\mathrm{H}_{1} \mathrm{~N}_{1}\right)$ pdmog-related severe outcomes compared with Denmark. Our results indicate that the adjuvanted pandemic vaccination may have had an impact on influenza type/subtype distribution and influenza-related severe outcomes in the season following the pandemic, although other factors may have also played a role.

We did not aim to answer the question about the most appropriate vaccination strategy during a pandemic. However, the study indicates that different vaccination strategies may have had consequences for the influenza season following the pandemic season and this should be part of an overall assessment of a pandemic response. In such an assessment the risk of severe and unexpected rare adverse events also needs to be taken into consideration when evaluating the risk/benefit of a pandemic vaccination campaign.
In order to support the assessment of vaccination strategies, we recommend the use of comprehensive influenza surveillance systems that, in addition to surveillance of influenza intensity and circulating subtypes, also include severe influenza-related outcomes to monitor changes in the impact of influenza between seasons across countries. We also recommend to keep the same surveillance systems in place in the seasons following the pandemic, in order to enable full evaluation of the impact of pandemic vaccination campaigns.

\section{The Nordic influenza comparison group}

Kåre Mølbak and Thea Kølsen Fischer, Statens Serum Institut, Copenhagen, Denmark, Annika Linde, Public Health Agency Sweden, Stockholm, Sweden and Haraldur Briem, Centre for Health Security and Communicable Disease Control, Reykjavik, Iceland.

\section{Acknowledgements}

We thank Jens Nielsen, Hanne-Dorthe Emborg and Sophie Gubbels for their support during the analysis and Pawel Stefanoff and Yvan Hutin for their critical review of the manuscript.

\section{Conflict of interest}

None declared

\section{Authors' contributions}

Julita Gil Cuesta wrote the study protocol, coordinated the data collection, analysed the data and wrote the manuscript. Kåre Mølbak and Annika Linde conceived the study. Tyra Grove Krause conceived the study, contributed with the data from her respective country and wrote the manuscript. Preben Aavitsland, Hélène Englund, Ólafur Gudlaugsson, Siri Helene Hauge, Outi Lyytikäinen, Guðrún Sigmundsdóttir, Anders Tegnell, and Mikko Virtanen contributed to the study design, contributed with the data from their respective countries and wrote the manuscript. The Nordic influenza comparison group contributed to the study design and critical review of the manuscript. All authors reviewed and approved the final version of the manuscript.

\section{References}

1. Pandemic influenza $A\left(\mathrm{H}_{1} \mathrm{~N}_{1}\right) 2009$ virus vaccine - conclusions and recommendations from the October 2009 meeting of the immunization Strategic Advisory Group of Experts. Wkly Epidemiol Rec. 2009;84(49):505-8.PMID: 19960623

2. Johansen K, Nicoll A, Ciancio BC, Kramarz P. Pandemic influenza $A\left(\mathrm{H}_{1} \mathrm{~N}_{1}\right) 2009$ vaccines in the European Union. Euro Surveill. 2009;14(41):19361.http://www.eurosurveillance.org/ ViewArticle.aspx?Articleld=19361PMID: 19883538

3. Wichmann O, Stöcker P, Poggensee G, Altmann D, Walter $D$, Hellenbrand W, et al. Pandemic influenza $A\left(\mathrm{H}_{1} \mathrm{~N}_{1}\right) 2009$ breakthrough infections and estimates of vaccine effectiveness in Germany 2009-2010. Euro Surveill. 2010;15(18):19561. http://www.eurosurveillance.org/ViewArticle. aspx?Articleld=19561PMID: 20460094

4. Puig-Barberà J, Arnedo-Pena A, Pardo-Serrano F, TiradoBalaguer MD, Pérez-Vilar S, Silvestre-Silvestre E, et al. Surveillance and Vaccine Evaluation Group during the autumn $2009 \mathrm{H}_{1} \mathrm{~N}_{1}$ pandemic wave in Castellón, Spain. Effectiveness of seasonal 2008-2009, 2009-2010 and pandemic vaccines, to prevent influenza hospitalizations during the autumn 2009 influenza pandemic wave in Castellón, Spain. A testnegative, hospital-based, case-control study.Vaccine. 
2010;28(47):7460-7. DOI: 10.1016/j.vaccine.2010.09.042 PMID: 20875486

5. Valenciano M, Kissling E, Cohen JM, Oroszi B, Barret AS, Rizzo C, et al. Estimates of pandemic influenza vaccine effectiveness in Europe, 2009-2010: results of Influenza Monitoring Vaccine Effectiveness in Europe (I-MOVE) multicentre case-control study. PLoS Med. 2011;8(1):e1000388. DOI: 10.1371/journal.pmed.1000388 PMID: 21379316

6. Hardelid P, Fleming DM, McMenamin J, Andrews N, Robertson C. Sebastian Pillai P, et al. Effectiveness of pandemic and seasonal influenza vaccine in preventing pandemic influenza $\mathrm{A}\left(\mathrm{H}_{1} \mathrm{~N}_{1}\right)_{2009}$ infection in England and Scotland 2009-2010. Euro Surveill. 2011;16(2):pii=19763. Available from:http://www. eurosurveillance.org/ViewArticle.aspx?Articleld=19763

7. Wu J, Xu F, Lu L, Lu M, Miao L, Gao T, et al. Safety and effectiveness of a $2009 \mathrm{H}_{1} \mathrm{~N}_{1}$ vaccine in Beijing. N Engl J Med. 2010;363(25):2416-23. DOI: 10.1056/NEJMoa1006736 PMID: 21158658

8. Widgren K, Magnusson M, Hagstam P, Widerström M, Örtqvist $\AA$, Einemo IM, et al. Prevailing effectiveness of the 2009 influenza $\mathrm{A}\left(\mathrm{H}_{1} \mathrm{~N}_{1}\right)$ pdmog vaccine during the $2010 / 11$ season in Sweden. Euro Surveill. 2013;18(15):20447.http://www. eurosurveillance.org/ViewArticle.aspx?Articleld=20447PMID: 23594578

9. Castilla J, Moran J, Martinez-Artola V, Reina G, Martinez-Baz I, Garcia Cenoz M, et al. Effectiveness of trivalent seasonal and monovalent influenza $A\left(\mathrm{H}_{1} \mathrm{~N}_{1}\right) 2009$ vaccines in population with major chronic conditions of Navarre, Spain: 2010/11 midseason analysis. Euro Surveill. 2011;16(7):19799.http://www. eurosurveillance.org/ViewArticle.aspx?Articleld=19799PMID: 21345321

10. Pebody R, Hardelid P, Fleming D, McMenamin J, Andrews N, Robertson C, et al. Effectiveness of seasonal 2010/11 and pandemic influenza $A\left(\mathrm{H}_{1} \mathrm{~N}_{1}\right) 2009$ vaccines in preventing influenza infection in the United Kingdom: mid-season analysis 2010/11. Euro Surveill. 2011;16(6):19791.http://www. eurosurveillance.org/ViewArticle.aspx?Articleld=19791PMID: 21329644

11. Eurostat. Available from: http://epp.eurostat.ec.europa.eu/ portal/page/portal/population/data/database

12. Kristiansen IS, Pedersen KM. [Health care systems in the Nordic countries--more similarities than differences?]. Tidsskr Nor Laegeforen. 2000;120(17):2023-9.PMID: 11008540

13. Nordic Medico-Statistical Committee 103:2015 (NOMESCO). Health Statistics in the Nordic Countries 2015. Copenhagen NOMESCO;2015. Available from: http://norden.diva-portal.org/ smash/get/diva2:874109/FULLTEXT01.pdf.

14. Mølbak K, Widgren K, Jensen KS, Ethelberg S, Andersen PH, Christiansen $A H$, et al. Burden of illness of the 2009 pandemic of influenza A ( $\left.\mathrm{H}_{1} \mathrm{~N}_{1}\right)$ in Denmark. Vaccine. 2011;29(Suppl 2):B63-9. DOI: 10.1016/j.vaccine.2011.03.064 PMID: 21757107

15. Lyytikainen O, Kuusi M, Snellman M, Virtanen M, Eskola J, Ronkko E, et al. Surveillance of influenza in Finland during the 2009 pandemic, 10 May 2009 to 8 March 2010. Euro Surveill. 2011;16(27):19908.http://www.eurosurveillance.org/ ViewArticle.aspx?Articleld=19908PMID: 21794216

16. Sigmundsdottir G, Gudnason T, Ólafsson Ö, Baldvinsdóttir GE, Atladottir A, Löve A, et al. Surveillance of influenza in Iceland during the 2009 pandemic. Euro Surveill. 2010;15(49):19742. http://www.eurosurveillance.org/ViewArticle. aspx?Articleld=19742PMID: 21163181

17. The Swedish Institute for Communicable Disease Control (Smittskyddsinstitutet). The Influenza A(H1N1)2009 Pandemic in Sweden, 2009-2010. 2011. Available from: http://www. folkhalsomyndigheten.se/

18. Direktoratet for samfunnssikkerhet of beredskap. Rapport Ny influenza $A\left(\mathrm{H}_{1} \mathrm{~N}_{1}\right)$ 2009. 2010. Available from: http://www.dsb. no/Global/Publikasjoner/2010/Rapporter/PandemiRapport.pdf

19. Gubbels S, Krause TG, Bragstad K, Perner A, Mølbak K, Glismann S. Burden and characteristics of influenza A and B in Danish intensive care units during the 2009/10 and 2010/11 influenza seasons. Epidemiol Infect. 2013;141(4):767-75. DOI: 10.1017/So950268812001471 PMID: 22793496

20. Guzmán Herrador BR, Aavitsland P, Feiring B, Riise Bergsaker $M A$, Borgen K. Usefulness of health registries when estimating vaccine effectiveness during the influenza $A\left(\mathrm{H}_{1} \mathrm{~N}_{1}\right)$ pdmog pandemic in Norway.BMC Infect Dis. 2012;12(1):63. DOI: 10.1186/1471-2334-12-63 PMID: 22429643

21. Voldstedlund M, Haarh M, Mølbak K, the MiBa Board of Representatives. The Danish Microbiology Database (MiBa) 2010 to 2013. Euro Surveill. 2014;19(1):pii=20667. DOI: http:// dx.doi.org/10.2807/1560-7917.ES2014.19.1.20667

22. Statens Serum Institut. Influenza-News - week 18, 2009. April 2009. Available from: http://www.ssi.dk/ /media/Indhold/ EN\%20-\%20engelsk/EPI-NEWS/2009/pdf/EPI-NEWS\%20-\%20 $2009 \% 20-\% 20 N_{0} \% 2018$.ashx
23. Statens Serum Institut. Influenza-News - week 27, 2009. July 2009. Available from: http://www.ssi.dk/ /media/Indhold/ EN\%20-\%20engelsk/EPI-NEWS/2009/pdf/EPI-NEWS\%20-\%20 2009\%20-\%20No\%2027-29.ashx

24. Aavitsland B, Blystad H, Hauge B, Borgen K, Hungnes F, Feiring B, et al. Folkehelseinstituttet under influensapandemien 2009 - Delrapport: Rådgivning. April 2013. Available from: http:// www.fhi.no/eway/default.aspx?pid=239\&trg=Content_6503\& Main $6157=6246: 0: 25,5498 \&$ MainContent $6246=6503: 0: 25,5$ 508\&Content_6503=6259:106167:25,5508:0:6250:1:::0:0

25. Danish Society for Infectious Diseases. Guidelines for management of influenza. Dec 2011. Danish. Available from: http://sundhedsstyrelsen.dk/ /media/327B287E85704D6ABE3 2DA4562CFoAE3.ashx

26. The Swedish Institute for Communicable Disease Control (Smittskyddsinstitutet). Influenza in Sweden. Season 2010-2011. Feb 2012. Available from: http://www. folkhalsomyndigheten.se/pagefiles/15028/influenza-insweden-2010-2011.pdf

27. O’Flanagan. Cotter S, Mereckiene J. Pandemic A(H1N1) 2009 Influenza Vaccination Survey, Influenza season 2009/2010. Venice II consortium. Available from: http://venice.cineca.org/ Final_Report_VENICE_Pandemic_Influenza_2009.pdf

28. Mølbak K, Widgren K, Jensen KS, Ethelberg S, Andersen PH, Christiansen $\mathrm{AH}$, et al. Burden of illness of the 2009 pandemic of influenza $A\left(\mathrm{H}_{1} \mathrm{~N}_{1}\right)$ in Denmark. Vaccine. 2011;29(Suppl 2):B63-9. DOI: 10.1016/j.vaccine.2011.03.064 PMID: 21757107

29. Blasio BF, Iversen BG, Tomba GS. Effect of vaccines and antivirals during the major $2009 \mathrm{~A}\left(\mathrm{H}_{1} \mathrm{~N}_{1}\right)$ pandemic wave in Norway--and the influence of vaccination timing.PLoS One. 2012;7(1):e30018. DOI: 10.1371/journal.pone.0030018 PMID: 22253862

30. Health Protection Agency. Surveillance of influenza and other respiratory viruses in the UK; 2011. Available from: http:// www.hpa.org.uk/webc/hpawebfile/hpaweb_c/1296687414154

31. Mytton OT, Rutter PD, Donaldson LJ, Influenza A. Influenza $A\left(\mathrm{H}_{1} \mathrm{~N}_{1}\right)$ pdmog in England, 2009 to 2011: a greater burden of severe illness in the year after the pandemic than in the pandemic year.Euro Surveill. 2012;17(14):20139.http://www. eurosurveillance.org/ViewArticle.aspx?Articleld=20139PMID: 22516004

32. Simpson CR, Ritchie LD, Robertson C, Sheikh A, McMenamin J. Effectiveness of $\mathrm{H}_{1} \mathrm{~N}_{1}$ vaccine for the prevention of pandemic influenza in Scotland, UK: a retrospective observational cohort study.Lancet Infect Dis. 2012;12(9):696-702. DOI: 10.1016 S1473-3099(12)70133-0 PMID: 22738894

33. Athanasiou M, Baka A, Andreopoulou A, Spala G, Karageorgou $\mathrm{K}$, Kostopoulos L, et al. Influenza surveillance during the postpandemic influenza 2010/11 season in Greece, 04 October 2010 to 22 May 2011. Euro Surveill. 2011;16(44):20004.http://www. eurosurveillance.org/ViewArticle.aspx?Articleld=20004PMID: 22085621

34. Health Protection Surveillance Centre. Influenza surveillance in Ireland - weekly update Influenza week 202010 (17th to 23rd May 2010). Dublin: Health Protection Surveillance Centre, May 2010. Available from: http://www.hpsc.ie/hpsc/A-Z/ Respiratory/Influenza/Seasonallnfluenza/Surveillance/ InfluenzaSurveillanceReports/PreviousInfluenzaSeasonsSurve illanceReports/20092010Season/File,4348,en.pdf

35. Skowronski DM, Janjua NZ, Hottes TS, De Serres G. Mechanism for seasonal vaccine effect on pandemic $\mathrm{H}_{1} \mathrm{~N}_{1}$ risk remains uncertain. Clin Infect Dis. 2011;52(6):831-2, author reply 832-3. DOI: $10.1093 /$ cid/ciro36 PMID: 21367740

36. Hardelid P, Andrews NJ, Hoschler K, Stanford E, Baguelin M, Waight PA, et al. Assessment of baseline age-specific antibody prevalence and incidence of infection to novel influenza A/ $\mathrm{H}_{1} \mathrm{~N}_{1}$ 2009. Health Technol Assess. 2010 Dec;14(55):115-92. doi: .

37. Waddington CS, Walker WT, Oeser C, Reiner A, John T, Wilkins $S$, et al. Safety and immunogenicity of ASo3B adjuvanted split virion versus non-adjuvanted whole virion $\mathrm{H}_{1} \mathrm{~N}_{1}$ influenza vaccine in UK children aged 6 months-12 years: open label, randomised, parallel group, multicentre study. BMJ. 2010;340(may27 1):c2649. DOI: 10.1136/bmj.c2649 PMID: 20508026

38. Vesikari T, Knuf M, Wutzler P, Karvonen A, KieningerBaum D, Schmitt HJ, et al. Oil-in-water emulsion adjuvant with influenza vaccine in young children. N Engl J Med. 2011;365(15):1406-16. DOI: 10.1056/NEJMoa1010331 PMID: 21995388

39. Syriänen RK, Jokinen J, Ziegler T, Sundman J, Lahdenkari M, Julkunen I, et al. Effectiveness of pandemic and seasonal influenza vaccines in preventing laboratory-confirmed influenza in adults: a clinical cohort study during epidemic seasons 2009-2010 and 2010-2011 in Finland. PLoS One. 2014;9(9):e108538. DOI: 10.1371/journal.pone.0108538 PMID: 25265186 
40. Skowronski DM, De Serres G, Crowcroft NS, Janjua NZ,

Boulianne N, Hottes TS, et al. , Canadian SAVOIR Team.

Association between the 2008-09 seasonal influenza

vaccine and pandemic $\mathrm{H}_{1} \mathrm{~N}_{1}$ illness during Spring-Summer 2009: four observational studies from Canada.PLoS Med. 2010;7(4):e1000258. DOI: 10.1371/journal.pmed.1000258 PMID: 20386731

41. Mereckiene J, Cotter S, Nicoll A, Lopalco P, Noori T, Weber JT, D’Ancona F, Lévy-Bruhl D, Dematte L, Giambi C, ValentinerBranth P, Stankiewicz I, Appelgren E, O'Flanagan D, the VENICE project gatekeepers group. Seasonal influenza immunisation in Europe. Overview of recommendations and vaccination coverage for three seasons: pre-pandemic (2008/09), pandemic (2009/10) and post-pandemic (2010/11). Euro Surveill. 2014;19(16): pii=20780. DOI: http://dx.doi. org/10.2807/1560-7917.ES2014.19.16.20780

42. O’Flanagan. Cotter S, Mereckiene J. Seasonal Influenza

Vaccination in EU/EEA, influenza season 2010-11 VENICE II Consortium. Available from: http://venice.cineca.org/Final Seasonal_Influenza_2010-11.pdf

\section{License and copyright}

This is an open-access article distributed under the terms of the Creative Commons Attribution (CC BY 4.0) Licence. You may share and adapt the material, but must give appropriate credit to the source, provide a link to the licence, and indicate if changes were made.

This article is copyright of the authors, 2016. 